\title{
METHODOLOGICAL TECHNIQUES FOR EVALUATING THE EFFICIENCY OF PRIVATE INVESTMENT IN EDUCATION
}

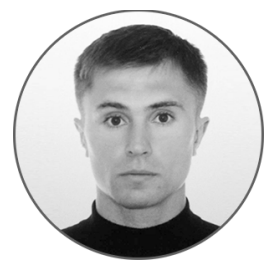

\section{Article history:}

Received 7 May 2018

Received in revised form

20 June 2018

Accepted 27 June 2018

Translated 4 February 2019

Available online 29 March 2019

JEL classification: G11,J24

Keywords: investment, education, human capital, productivity, potential income

\author{
Igor'A. BUKREEV \\ V.I. Vernadsky Crimean Federal University, Yalta, Russian Federation \\ bukreev.igor@bk.ru \\ https://orcid.org/0000-0002-6903-946X
}

\begin{abstract}
Subject The article discusses the methodological approaches to evaluating the efficiency of private investment in human capital as a self-expanding value driver. I spotlight education as a crucial component of human capital, which is considered as the self-expanding value driven by an increase in the staff labor productivity, salaries. I also treat it as the property represented with professional qualities.

Objectives The research aims to forge a technique for evaluating the cost effectiveness of investment in education as part of human capital investment by comparing income (average salaries at different levels of education) and training expenditures.

Methods I determined the required rate of return on investment in education, considering the use of alternative manpower and finance.

Results The rate of return is taken as equal tranches of additional income (annuity) throughout the entire employment period, including investment in education, and income lost for the period of training as alternative costs. Based on real indicators, I precisely measured the net return on investment in education at different levels. Conclusions and Relevance The technique allows to determine whether a person effectively utilizes labor and financial resources as investment in education. The technique can be applied to evaluate the efficiency of private investment and require rate of return on investment in education.
\end{abstract}

๑) Publishing house FINANCE and CREDIT, 2018

The editor-in-charge of this article was Irina M. Vechkanova Authorized translation by Irina M. Vechkanova

Education should be viewed as an item of investment in human capital. The concept human capital stemmed from key criteria of capital, being the self-expanding value driven by an increase in the personal labor productivity, salary, and property represented with professional qualities.

As Adam Smith noted in The Inquiry into the Nature and Causes of the Wealth of Nations [1], the useful labor becomes more productive after the employee improves

${ }^{\dagger}$ For the source article, please refer to: Букреев И.А. Методические подходы к оценке эффективности частного инвестирования в образование // Финансовая аналитика: проблемы и решения. 2018. T. 11. № 4. C. 387-400.

URL: https://doi.org/10.24891/fa.11.4.387 his/her professional skills, with the subsequent technological upgrade of machines and tools. The renowned scholar treated investment as contributions to the human ability to earn in the future, likening them with the physical property, which are supposed to pay back within the employment life of a person [2].

Alfred Marshall suggested capitalizing net earnings in evaluating the human capital, emphasizing the similarity of investment in human capital and capital stock. Like A. Smith, A. Marshall advocated an economic approach to people, treating them as capital [3-6].

Drawing upon the concepts by A. Smith and D. Ricardo, K. Marx developed the theory of productive force 
reproduction, considering a man as the capital stock and emphasized that professional knowledge, productive skills and spare time were of paramount importance for the human development [5-8].

Th. Schulz was one of the trailblazers in human capital investment, introducing the notion and referring it to people's accumulation of professional knowledge, effective and productive performance for the public interest and health care.

Before the origination of the neoclassical theory of human capital, K. Marx qualified human capital investment as part of productive force reproduction costs. Th. Schulz echoed the idea stating that human capital can be accumulated and reproduced $[9,10]$.

L. Walras and J.R. McCullox proclaimed the human to be capital since they believed that personal skills and capabilities are inseparable of a person. Likewise, they mentioned the required rate of return on investment and time spent to get special training as the necessary rate at which wages shall be augmented [11, 12].

The concept and principles of the human capital theory are believed to have been introduced by the U.S. scholar Th. Schulz, while H. Becker [13] developed a microeconomic analysis method to study various aspects of human behavior and interactions. Th. Schulz evaluated human capital investment through the same categories as physical capital, considering expenditures on education and respective time.

G. Psacharopoulos, H.A. Patrinos [14], J.B. Mincer [15] and G.S. Becker, B.R. Chiswick [16] proposed approaches to measuring the return on human capital investment.

Types of human capital investment [17]:

- expenditure on education, including secondary school and vocational, formal and information training;

- healthcare expenditures made up of the preventative treatment, medical services, diet, better housing and living conditions;

- mobility expenditures people incurred to migrate from places with low productivity, wages and working conditions.

As K.Marx and T. Hodgskin note, human capability to work is the main wealth-generating asset generated as a result of the prior work. The issue of capabilities is considered as the public benefit.
From perspectives of personal benefit, human capital (productive force, constructive, namely intellectual, capabilities of a person, according to $\mathrm{K}$. Marx) can really be accumulated, but not as the inert mass as compared with physical capital, but rather a living construct, being the art of a worker and degree of labor advancement $[7,8]$.

According to K. Marx, the developed productive force resolves itself into the complex spirit, though it can turn up as something simpler. The mere productive force, under no circumstance, cannot be embodies as a piece of complex work. The complexity and quality of work reflect the development of productive force, which concurrently unites the consumption and production of physical and intellectual capabilities $[18,19]$.

Nowadays, it is clear that human capital investment paves the way for the developed countries to technological advancement, making them more and more competitive. Furthermore, the cost effectiveness of investment in education depends on the development level of a specific country. It is necessary to keep track of education spending as precise as practicable and determine their effectiveness so to reduce gross labor costs in all areas of social reproduction.

It is not that easy to gauge the economic effect of investment in education from individual perspectives since the consumer lacks the information needed to assess possible benefits as appropriate..

G.S. Becker framed the concept of individual demand curve with respect to investment in education. The investment demand curve accounts for increasing physical and intellectual requirements, income lost during the training period, reduction in the income generation time in case of the closing stage investment, increased risk in case of greater investment. The researcher assessed the cost effectiveness of education by deducting earnings of those who continued their education after high school from lifetime earnings of those who graduated from colleges $[20,21]$.

According to international researches, there is a 60 percent correlation between the level of income and education (UNESCO data). In this respect, we can point out some trends ${ }^{1}$ :

- the remuneration of better education employees is higher than those with the lower educational level;

${ }^{1}$ EFA Global Monitoring Report, 12th edition. URL: http://unesdoc.unesco.org/images/0023/002325/232565R.pdf 
- remuneration grows as an employee gets older and more experienced;

- the better the educational background, the later a person reaches the maximum wage.

It is noteworthy that if it is an employee who decides on his/her educational needs, he/she should consider the tuition cost, earnings lost during studies and the interest rate. Private costs will include any direct expenses to be incurred by a person and income lost.

Investment in education and return on it are two processes distanced over time. Thus, they should be brought to the same moment to be compared. Net Present Value (NPV) is the difference between the discounted values of net present flows of benefits and costs. Investment in further education is feasible and reasonable if NPV is positive[21-24].

The following values are used to measure the economic effect of investment in education:

1) average remuneration of employees by competence and education (Table 1);

2) annual tuition fees and duration of full-time training by education level (Table 1);

3) refinance rate $i$ and inflation rate $T$ (Table 2);

4) average employment record upon retirement (it is 34.5 years in Russia. I use 30 years to simplify computations) ${ }^{2}$.

There was a trend in Russia that more well educated employees are better paid than those with lover educational level. However, the trend has been declining for the recent years due to a lack of qualified workforce, but it is still considerable (Table 1).

In Russia, people of different educational background may earn quite similar income unlike the situation in advanced economies. However, the cost of education is too high from perspectives of the existing income levels.

As for the accounting rate, it is much higher than in advanced economies, thus making investment in education not very lucrative. Table 2 presents the fluctuating refinance rate and inflation rate for 2008-2017.

As the computations show, for planning purposes, it is unreasonable to refer to the refinance rate and inflation

\footnotetext{
${ }^{2}$ REGNUM. Average employment history upon retirement is 34.5 years in Russia. URL: http://regnum.ru/news/1734236.html (In Russ.)
}

rate. To evaluate the efficiency of investment in education, indicators of the stable economic situation, which is recorded by the Central Bank of Russia, matter only.

The Central Bank accepts the equilibruim rate of interest as much as 6.5-7 percent per annum. It will settle in 2019. According to the Central Bank of Russia, the interest rate should be 2.5-3 points higher in case of a 4-percent stable inflation. Therefore, I use indicators of the stable economic development that are captured in case of a 4-percent inflation rate and 7percent refinance rate.

Investment in education include tuition fees at different levels of professional training and income lost during the period of such training, which can be measured with the average salary a person might earn, having just secondary education.

Investment in education and possible income represented with the average salary of a person with secondary education take a certain moment of time within the period when a person attends a professional advancement course. Thus, the future fees should be taken into consideration. Benefits from such investment shall translate into higher income in the future, thus raising the future value of investment in education.

Costs of investment in education can be direct (tuition fees) and alternative (probable salary which a person without special professional training may earn). Additional income should be taken into account as equal parts as if the return on investment in education was generated part by part plus interests on their par value (Table 3).

As the computations show, different education background may possibly generate earnings of RUB 8,335 up to RUB 11,579 per month additionally to the average salary base.

The nominal value of the future average salary will equal RUB 30,351 in four years' time, without its real value being changed as per the compound interest formula and inflation rate for the period of stable economic development $(T=7 \%)$. The future amount of tuition fees and salary (alternative costs) will constitute the cost of education in line with the average salary base for the given period (Table 4-6).

Unless the real value changes throughout the period, the nominal salary will range from RUB 30,351 to RUB 98,440 . In such circumstances, the ratio of additional 
potential earnings will reach the highest record within the time period, i.e. 0.38 to 0.12 (Table 4).

The ratio of additional potential earnings will range from 0.28 to 0.09 (Table 5).

The ratio of additional potential earnings will range from 0.27 to 0.08 (Table 6).

The real refinance rate $R_{c}(i)=0.029$ should be used to describe the rate of return on investment in education. The real refinance rate help measure the real amount of additional earnings. I apply such values to demonstrate whether earnings are substantial (Table 7).

After computations are made in accordance with the real interest rate of monthly additional earnings, which represent the rate of return on investment in education, the real salary can be compared at different levels of educational background. The comparison refers to the secondary education level (Table 8).

Relying upon the given data, I can underline the positive net return on higher education only, amounting to RUB 13,154.4 per month. Under the real economic circumstances, there is frequent demand for qualified workforce, especially in utilities and servicing sectors. The value of such workers' services considerably exceeds the average indicator given in Table 1 as compared with working time spent. In this case, the worker also acts as an entrepreneur, searching for orders on his/her own and considering payments for such services as his/her own income.

Analyzing Table 9, I conclude that the return on investment in education increases as the qualification level is raised. Leadership positions generate the highest positive return. However, it is negative at the line level. Hence, the payback period of investment in education depends on the professional promotion dynamics or the period of working in a line position being as short as possible.

If education is treated as investment and likened to investment in capital stock, the proposed technique for efficiency evaluation from perspectives of an individual allows to understand the required rate of return on investment in different levels of education through the salary difference.

The computations herein are relevant since they help measure net earnings from different educational background as a whole and in particular, from perspectives of an individual as an economic entity.

K. Marx's theory describes the situation when capital migrate from one industry to the other until prices for goods ensure equal profit for equal capital held in different industries. The same approach works in the proposed technique to measure the required rate of return on investment in different levels of education.

Like a businessman gains abnormal return, pioneering a sector with the high rate of return on investment, an individual, who monitors the labor market demand, is also able to evaluate his/her investment in education with the proposed technique as an opportunity of net income, which is similar to abnormal return.

Furthermore, the technique can serve for the economic rationale for the offering of education services. 


\section{Table 1}

The average salary of employees by occupation group and educational level in 2015, RUB

\begin{tabular}{lllll}
\hline Group & \multicolumn{3}{l}{ Education level } & \\
\cline { 2 - 5 } & Higher & $\begin{array}{l}\text { Secondary vocational } \\
\text { education, mid-level specialist }\end{array}$ & $\begin{array}{l}\text { Secondary vocational } \\
\text { education, professionally } \\
\text { skilled worker, white collar } \\
\text { employee }\end{array}$ & $\begin{array}{l}\text { Secondary } \\
\text { education }\end{array}$ \\
\hline Entire staff & & & 27,128 & 25,944 \\
\hline Leaders & & & 39,729 & 38,239 \\
\hline High qualification staff & 43,362 & 26,929 & 28,983 & 33,099 \\
\hline Mid-level qualification staff & 65,587 & 42,022 & 25,118 & 26,056 \\
\hline General workers (baseline level) & 39,056 & 28,345 & 15,530 & 15,771 \\
\hline Tuition fees & 37,765 & 27,334 & 56,000 & - \\
\hline Duration of training, years & 17,422 & 15,221 & 3 & - \\
\hline
\end{tabular}

Source: 2017 Chart Education: A Statistical Compendium. URL: https://www.hse.ru/data/2017/05/29/1172124724/\%D0\%98\%D0\%BD \%D0\%B4\%D0\%B8\%D0\%BA\%D0\%B0\%D1\%82\%D0\%BE\%D1\%80\%D1\%8B\%20\%D0\%BE\%D0\%B1\%D1\%80\%D0\%B0\%D0\%B7\%D0\%BE \%D0\%B2\%D0\%B0\%D0\%BD\%D0\%B8\%D1\%8F\%202017.pdf (In Russ.); The cost of higher education in the Universities of Moscow. Investing in the future. URL: http://www.aif.ru/boostbook/stoimost-vysshego-obrazovanija.html (In Russ.); Totals and Size Make Up the Basic Standard Costs for Cost Groups of Professions and Specialities for the Realization of the Basic Professional Education Programs Vocational-Training Programs Mid-level Professionals in 2015 Year for Institutions Subordinated to the Ministry of Education and Science of Russia. URL: https://минобрнауки.рф/документы/5660 (In Russ.)

\section{Table 2}

Key macroeconomic indicators in 2008-2017, percent

\begin{tabular}{lllll}
\hline Year & $\begin{array}{l}\text { Inflation rate in } \\
\text { Russia per annum }\end{array}$ & Inflation, growth rate & Refinance rate range & Average refinance rate (ratio) \\
\hline 2017 & 1.03 & 0.02 & $7.75-9.75$ & 0.08 \\
\hline 2016 & 1.05 & 0.05 & $10-10.5$ & 0.1 \\
\hline 2015 & 1.13 & 0.13 & $11.5-15$ & 0.13 \\
\hline 2014 & 1.11 & 0.11 & $7-17$ & 0.12 \\
\hline 2013 & 1.06 & 0.06 & 5.5 & 0.06 \\
\hline 2011 & 1.07 & 0.07 & 8.25 & 0.08 \\
\hline 2010 & 1.06 & 0.06 & $8-8.25$ & 0.08 \\
\hline 2009 & 1.09 & 0.09 & $7.75-8.5$ & 0.08 \\
\hline 2008 & 1.09 & 0.09 & $8.75-12.5$ & 0.11 \\
\hline
\end{tabular}

Source: Inflation on the Consumer Market. URL: http://www.cbr.ru/statistics/?Prtld=macro_sub (In Russ.); The Inflation Statement by the Central Bank. URL: https://www.bfm.ru/news/339731; Information about the CBR Refinancing Rate.

URL: http://nalognalog.ru/spravochnaya_informaciya/informaciya_o_stavke_refinansirovaniya_cb_rf (In Russ.) 
Table 3

Key indicators for computations in line with the nominal interest rate

\begin{tabular}{|c|c|c|c|c|}
\hline Indicator & Formula & Higher education & $\begin{array}{l}\text { Secondary vocational } \\
\text { education, mid-level } \\
\text { specialist }\end{array}$ & $\begin{array}{l}\text { Secondary vocational } \\
\text { education, professionally } \\
\text { skilled worker, white collar } \\
\text { employee }\end{array}$ \\
\hline $\begin{array}{l}\text { Cost of education (including } \\
\text { alternative costs) as of the } \\
\text { beginning of the period, } F V\end{array}$ & $\begin{array}{l}F V=C F_{0}(1+i)^{n}+ \\
+C F_{1}(1+i)^{n-1}+\ldots \\
+C F_{n}(1+l)^{n-n}= \\
=\sum C F_{k}(1+i)^{n-k}, \\
\text { where } C F_{0} \ldots C F_{k} \text { mean money spent in } \\
\text { different periods }(n-k) ; \\
i \text { is the refinance rate }\end{array}$ & $1,724,331.78$ & $1,251,998.83$ & $1,241,266.2$ \\
\hline $\begin{array}{l}\text { Future value of regular } \\
\text { payment in the same } \\
\text { monetary unit, } a_{n}\end{array}$ & $a_{n}=i /\left\{1-\left[1 /(1+l)^{n}\right]\right\}$ & 0.081 & 0.081 & 0.081 \\
\hline $\begin{array}{l}\text { Future potential income per } \\
\text { year, } A a_{n,} \text { RUB }\end{array}$ & $\begin{array}{l}A a_{n}=a_{n} \sum, \\
\text { where } \Sigma \text { is the amount invested in } \\
\text { education }\end{array}$ & $138,957.7$ & $100,894.08$ & $100,029.18$ \\
\hline $\begin{array}{l}\text { Future potential income per } \\
\text { month, RUB }\end{array}$ & $A a_{n} / 12$ & $11,579.81$ & $8,407.84$ & $8,335.76$ \\
\hline
\end{tabular}

Source: Authoring

Table 4

Assessment of additional income as an alternative to higher education, RUB ${ }^{*}$

\begin{tabular}{lllllll}
\hline Year & Nominal salary & Ratio of salary & $\begin{array}{l}\text { Cost of education, including } \\
\text { alternative costs, as of the } \\
\text { beginning of the period }\end{array}$ & $\begin{array}{l}\text { Interests per annum } \\
\text { on funds equal to the } \\
\text { cost of education }\end{array}$ & $\begin{array}{l}\text { Accumulated funds } \\
\text { in line with interests } \\
\text { accrued }\end{array}$ & $\begin{array}{l}\text { Amount as of the } \\
\text { end of each year }\end{array}$ \\
\hline 1 & 30,351 & 0.38 & $1,724,331.8$ & $120,703.2$ & $1,845,035$ & $1,706,077.3$ \\
\hline 2 & 32,827 & 0.35 & $1,706,077.3$ & $119,425.4$ & $1,825,502.7$ & $1,686,545$ \\
\hline 3 & 34,141 & 0.34 & $1,686,545$ & $118,058.2$ & $1,804,603.2$ & $1,665,645.5$ \\
\hline 4 & 35,506 & 0.33 & $1,665,645.5$ & $116,595.2$ & $1,782,240.7$ & $1,643,283$ \\
\hline 5 & 36,926 & 0.31 & $1,643,283$ & $115,029.8$ & $1,758,312.8$ & $1,619,355.1$ \\
\hline 6 & 38,403 & 0.3 & $1,619,355.1$ & $113,354.9$ & $1,732,709.9$ & $1,593,752.2$ \\
\hline 7 & 39,940 & 0.29 & $1,593,752.2$ & $111,562.7$ & $1,705,314.9$ & $1,566,357.2$ \\
\hline 8 & 41,537 & 0.28 & $1,566,357.2$ & 109,645 & $1,676,002.2$ & $1,537,044.5$ \\
\hline 9 & 43,199 & 0.27 & $1,537,044.5$ & $107,593.1$ & $1,644,637.6$ & $1,505,679.9$ \\
\hline 10 & 44,927 & 0.26 & $1,505,679.9$ & $1,95,397.6$ & $1,611,077.5$ & $1,472,119.8$ \\
\hline 11 & 46,724 & 0.25 & $1,472,119.8$ & $103,048.4$ & $1,575,168.2$ & $1,436,210.5$ \\
\hline 12 & 48,593 & 0.24 & $1,436,210.5$ & $100,534.7$ & $1,536,745.2$ & $1,397,787.5$ \\
\hline 13 & 50,536 & 0.23 & $1,397,787.5$ & $97,845.1$ & $1,495,632.7$ & $1,356,675$ \\
\hline 14 & 52,558 & 0.22 & $1,356,675$ & $94,967.2$ & $1,451,642.2$ & $1,312,684.5$ \\
\hline 15 & 54,660 & 0.21 & $1,312,684.5$ & $91,887.9$ & $1,404,572.5$ & $1,265,614.8$ \\
\hline 16 & 56,846 & 0.2 & $1,265,614.8$ & 88,593 & $1,354,207.8$ & $1,215,250.1$ \\
\hline 17 & 59,120 & 0.2 & $1,215,250.1$ & $85,067.5$ & $1,300,317.6$ & $1,161,359.9$ \\
\hline 18 & 61,485 & 0.19 & $1,161,359.9$ & $81,295.2$ & $1,242,655.1$ & $1,103,697.4$ \\
\hline 19 & 63,945 & 0.18 & $1,103,697.4$ & $77,258.8$ & $1,180,956.2$ & $1,041,998.5$ \\
\hline 20 & 66,502 & 0.17 & $1,041,998.5$ & $72,939.9$ & $1,114,938.4$ & $975,980.7$ \\
\hline & & & & & &
\end{tabular}

Please cite this article as: Bukreev I.A. Methodological Techniques for Evaluating the Efficiency of Private Investment in Education. Digest 
I.A. Bukreev / Digest Finance, 2019, volume 24, issue 1, pages 53-63

\begin{tabular}{lllllll}
\hline 21 & 69,162 & 0.17 & $975,980.7$ & $68,318.7$ & $1,044,299.4$ & $905,341.7$ \\
\hline 22 & 71,929 & 0.16 & $905,341.7$ & $63,373.9$ & $968,715.6$ & $829,757.9$ \\
\hline 23 & 74,806 & 0.15 & $829,757.9$ & $58,083.1$ & $887,840.9$ & $748,883.2$ \\
\hline 24 & 77,798 & 0.15 & $748,883.2$ & $52,421.8$ & $801,305.1$ & $662,347.4$ \\
\hline 25 & 80,910 & 0.14 & $662,347.4$ & $46,364,3$ & $708,711.7$ & 569,754 \\
\hline 26 & 84,147 & 0.14 & 569,754 & $39,882,8$ & $609,636.8$ & $470,679.1$ \\
\hline 27 & 87,513 & 0.13 & $470,679.1$ & $32,947.5$ & $503,626.6$ & $364,668.9$ \\
\hline 28 & 91,013 & 0.13 & $364,668.9$ & $25,526.8$ & $390,195.7$ & 251,238 \\
\hline 29 & 94,654 & 0.12 & 251,238 & $17,586.7$ & $268,824.7$ & 129,867 \\
\hline 30 & 98,440 & 0.12 & 129,867 & $9,090.7$ & $138,957.7$ & 0 \\
\hline
\end{tabular}

Additional potential income for the employment period amounts to RUB 138,957.7.

Source:Authoring

Table 5

Assessment of additional income as an alternative to secondary vocational training of a mid-level specialist, RUB

\begin{tabular}{|c|c|c|c|c|c|c|}
\hline Year & Nominal salary & $\begin{array}{l}\text { Percentage of the } \\
\text { salary }\end{array}$ & $\begin{array}{l}\text { The cost of education, } \\
\text { including alternative costs, as } \\
\text { of the beginning of the } \\
\text { period }\end{array}$ & $\begin{array}{l}\text { Interests per annum } \\
\text { accrued on funds } \\
\text { equal to the cost of } \\
\text { education }\end{array}$ & $\begin{array}{l}\text { Accumulation of the } \\
\text { funds, including } \\
\text { interests accrued }\end{array}$ & $\begin{array}{l}\text { Funds as of the } \\
\text { end of each } \\
\text { year }\end{array}$ \\
\hline 1 & 30,351 & 0.28 & $1,251,998.8$ & $87,639.9$ & $1,339,638.7$ & $1,238,744.7$ \\
\hline 2 & 32,827 & 0.26 & $1,238,744.7$ & $86,712.1$ & $1,325,456.8$ & $1,224,562.7$ \\
\hline 3 & 34,141 & 0.25 & $1,224,562.7$ & $85,719.4$ & $1,310,282.1$ & $1,209,388$ \\
\hline 4 & 35,506 & 0.24 & $1,209,388$ & $84,657.2$ & $1,294,045.2$ & $1,193,151.1$ \\
\hline 5 & 36,926 & 0.23 & $1,193,151.1$ & $83,520.6$ & $1,276,671.7$ & $1,175,777.6$ \\
\hline 6 & 38,403 & 0.22 & $1,175,777.6$ & $82,304.4$ & $1,258,082$ & $1,157,187.9$ \\
\hline 7 & 39,940 & 0.21 & $1,157,187.9$ & $81,003.2$ & $1,238,191.1$ & $1,137,297$ \\
\hline 8 & 41,537 & 0.2 & $1,137,297$ & $79,610.8$ & $1,216,907.8$ & $1,116,013.7$ \\
\hline 9 & 43,199 & 0.19 & $1,116,013.7$ & 78,121 & $1,194,134.7$ & $1,093,240.6$ \\
\hline 10 & 44,927 & 0.19 & $1,093,240.6$ & $76,526.8$ & $1,169,767.4$ & $1,068,873.3$ \\
\hline 11 & 46,724 & 0.18 & $1,068,873.3$ & $74,821.1$ & $1,143,694.5$ & $1,042,800.4$ \\
\hline 12 & 48,593 & 0.17 & $1,042,800.4$ & 72,996 & $1,115,796.4$ & $1,014,902.3$ \\
\hline 13 & 50,536 & 0.17 & $1,014,902.3$ & $71,043.2$ & $1,085,945.5$ & $985,051.4$ \\
\hline 14 & 52,558 & 0.16 & $985,051.4$ & $68,953.6$ & $1,054,005$ & $953,110.9$ \\
\hline 15 & 54,660 & 0.15 & $953,110.9$ & $66,717.8$ & $1,019,828.7$ & $918,934.6$ \\
\hline 16 & 56,846 & 0.15 & $918,934.6$ & $64,325.4$ & $983,260.1$ & 882,366 \\
\hline $17-\breve{~}$ & 59120 & 0,14 & 882,366 & $61,765.6$ & $944,131.6$ & $843,237.5$ \\
\hline 18-й & 61485 & 0,14 & $843,237.5$ & $59,026.6$ & $902,264.1$ & 801,370 \\
\hline 19-й & 63945 & 0,13 & 801,370 & $56,095.9$ & $857,465.9$ & $756,571.9$ \\
\hline 20-й & 66502 & 0,13 & $756,571.9$ & 52,960 & $809,531.9$ & $708,637.8$ \\
\hline 21-й & 69162 & 0,12 & $708,637.8$ & $49,604.6$ & $758,242.5$ & $657,348.4$ \\
\hline $22-и ̆$ & 71929 & 0,12 & $657,348.4$ & $46,014.4$ & $703,362.8$ & $602,468.7$ \\
\hline $23-и ̆$ & 74806 & 0,11 & $602,468.7$ & $42,172.8$ & $644,641.5$ & $543,747.4$ \\
\hline 24-й & 77798 & 0,11 & $543,747.4$ & $38,062.3$ & $581,809.7$ & $480,915.6$ \\
\hline $25-и ̆$ & 80910 & 0,1 & $480,915.6$ & $33,664.1$ & $514,579.7$ & $413,685.7$ \\
\hline $26-и ̆$ & 84147 & 0,1 & $413,685.7$ & 28,958 & $442,643.7$ & $341,749.6$ \\
\hline $27-и ̆$ & 87513 & 0,1 & $341,749.6$ & $23,922.5$ & 365,672 & 264,778 \\
\hline $28-и ̆$ & 91013 & 0,09 & 264,778 & $18,534.5$ & $283,312.4$ & $182,418.3$ \\
\hline 29-й & 94654 & 0,09 & $182,418.3$ & $12,769.3$ & $195,187.6$ & $94,293.5$ \\
\hline 30-й & 98440 & 0,09 & $94,293.5$ & $6,600.5$ & $100,894.1$ & 0 \\
\hline
\end{tabular}

Additional potential income for the employment period amounts to RUB 100,894.1.

Source:Authoring

Please cite this article as: Bukreev I.A. Methodological Techniques for Evaluating the Efficiency of Private Investment in Education. Digest Finance, 2019, vol. 24, iss. 1, pp. 53-63.

https://doi.org/10.24891/df.24.1.53 
Table 6

Assessment of additional income as an alternative to secondary education of a professionally skilled worker, employee, RUB *

\begin{tabular}{|c|c|c|c|c|c|c|}
\hline Year & Nominal salary & $\begin{array}{l}\text { Percentage of } \\
\text { salary }\end{array}$ & $\begin{array}{l}\text { The cost of education, } \\
\text { including alternative costs, as } \\
\text { of the beginning of the } \\
\text { period }\end{array}$ & $\begin{array}{l}\text { Interests per annum } \\
\text { accrued on funds } \\
\text { equal to the cost of } \\
\text { education }\end{array}$ & $\begin{array}{l}\text { Accumulation of the } \\
\text { funds, including } \\
\text { interests accrued }\end{array}$ & $\begin{array}{l}\text { Funds as of the } \\
\text { end of each } \\
\text { year }\end{array}$ \\
\hline 1 & 30,351 & 0.27 & $1,241,266.2$ & $86,888.6$ & $1,328,154,8$ & $1,228,125.7$ \\
\hline 2 & 32,827 & 0.25 & $1,228,125.7$ & $85,968.8$ & $1,314,094,5$ & $1,214,065.3$ \\
\hline 3 & 34,141 & 0.24 & $1,214,065.3$ & $84,984.6$ & $1,299,049,8$ & $1,199,020.7$ \\
\hline 4 & 35,506 & 0.23 & $1,199,020.7$ & $83,931.4$ & $1,282,952,1$ & $1,182,922.9$ \\
\hline 5 & 36,926 & 0.23 & $1,182,922.9$ & $82,804.6$ & $1,265,727,5$ & $1,165,698.4$ \\
\hline 6 & 38,403 & 0.22 & $1165,698.4$ & $81,598.9$ & $1,247,297,2$ & $1,147,268.1$ \\
\hline 7 & 39,940 & 0.21 & $1147,268.1$ & $80,308.8$ & $1,227,576,8$ & $1,127,547.7$ \\
\hline 8 & 41,537 & 0.2 & $1,127,547.7$ & $78,928.3$ & $1,206,476$ & $1,106,446.8$ \\
\hline 9 & 43,199 & 0.19 & $1,106,446.8$ & $77,451.3$ & $1,183,898,1$ & $1,083,868.9$ \\
\hline 10 & 44,927 & 0.19 & $1,083,868.9$ & $75,870.8$ & $1,159,739,7$ & $1,059,710.5$ \\
\hline 11 & 46,724 & 0.18 & $1,059,710.5$ & $74,179.7$ & $1,133,890,3$ & $1,033,861.1$ \\
\hline 12 & 48,593 & 0.17 & $1,033,861.1$ & $72,370.3$ & $1,106,231,4$ & $1,006,202.2$ \\
\hline 13 & 50,536 & 0.16 & $1,006,202.2$ & $70,434.2$ & $1,076,636,4$ & $976,607.2$ \\
\hline 14 & 52,558 & 0.16 & $976,607.2$ & $68,362.5$ & $1,044,969,7$ & $944,940.5$ \\
\hline 15 & 54,660 & 0.15 & $944,940.5$ & $66,145.8$ & $1,011,086,3$ & $911,057.2$ \\
\hline 16 & 56,846 & 0.15 & $911,057.2$ & 63,774 & $974,831,2$ & 874,802 \\
\hline 17 & 59,120 & 0.14 & 874,802 & $61,236.1$ & $936,038,1$ & $836,008.9$ \\
\hline 18 & 61,485 & 0.14 & $836,008.9$ & $58,520.6$ & $894,529,6$ & $794,500.4$ \\
\hline 19 & 63,945 & 0.13 & $794,500.4$ & 55,615 & $850,115,4$ & $750,086.2$ \\
\hline 20 & 66,502 & 0.13 & $750,086.2$ & 52,506 & $802,592,3$ & $702,563.1$ \\
\hline 21 & 69,162 & 0.12 & $702,563.1$ & $49,179.4$ & $751,742,5$ & $651,713.3$ \\
\hline 22 & 71,929 & 0.12 & $651,713.3$ & $45,619.9$ & $697,333,3$ & $597,304.1$ \\
\hline 23 & 74,806 & 0.11 & $597,304.1$ & $41,811.3$ & $639,115,4$ & $539,086.2$ \\
\hline 24 & 77,798 & 0.11 & $539,086.2$ & 37,736 & $576,822,2$ & 476,793 \\
\hline 25 & 80,910 & 0.1 & 476,793 & $33,375.5$ & $510,168,6$ & $410,139.4$ \\
\hline 26 & 84,147 & 0.1 & $410,139.4$ & $28,709.8$ & $438,849,1$ & 338,820 \\
\hline 27 & 87,513 & 0.1 & 338,820 & $23,717.4$ & $362,537,4$ & $262,508.2$ \\
\hline 28 & 91,013 & 0.09 & $262,508.2$ & $18,375.6$ & $280,883,8$ & $180,854.6$ \\
\hline 29 & 94,654 & 0.09 & $180,854.6$ & $12,659.8$ & $193,514,4$ & $93,485.2$ \\
\hline 30 & 98,440 & 0.08 & $93,485.2$ & 6,544 & $100,029,2$ & 0 \\
\hline
\end{tabular}

Additional potential income for the employment period amounts to RUB 100,029.2.

Source:Authoring 


\section{Table 7}

Key indicators for computations in line with the real interest rate

\begin{tabular}{|c|c|c|c|c|}
\hline Indicators & Formula & $\begin{array}{l}\text { Higher } \\
\text { education }\end{array}$ & $\begin{array}{l}\text { Secondary vocational education, } \\
\text { mid-level specialist }\end{array}$ & $\begin{array}{l}\text { Secondary vocational education, } \\
\text { professionally skilled worker, white } \\
\text { collar employee }\end{array}$ \\
\hline $\begin{array}{l}\text { Real interest rate, } R_{C}(i) \text {, } \\
\%\end{array}$ & $R_{C}(i)=(1+/) /(1+T)-1$ & 0.029 & 0.029 & 0.029 \\
\hline $\begin{array}{l}\text { Real future value of } \\
\text { regular payments in the } \\
\text { same monetary unit, } \\
a_{n r}\end{array}$ & $a_{n r}=i /\left\{1-\left[1 /(1+/)^{n}\right]\right\}$ & 0.05 & 0.05 & 0.05 \\
\hline $\begin{array}{l}\text { Future potential } \\
\text { income per year, } A_{a n r} \text {, } \\
\text { RUB }\end{array}$ & $\begin{array}{l}A_{a n r}=a_{n r} \Sigma \\
\text { where } r \text { is a real value }\end{array}$ & $86,667.09$ & $62,927.04$ & $62,387.6$ \\
\hline $\begin{array}{l}\text { Future potential } \\
\text { income per month, RUB }\end{array}$ & $A_{a n r} / 12$ & $7,222.26$ & $5,243.92$ & $5,198.97$ \\
\hline
\end{tabular}

Source:Authoring

\section{Table 8}

Return on investment in education, RUB

\begin{tabular}{llll}
\hline Indicator & \multicolumn{2}{l}{ Higher education } & \\
\cline { 2 - 4 } & Higher & $\begin{array}{l}\text { Secondary vocational education, } \\
\text { mid-level specialist }\end{array}$ & $\begin{array}{l}\text { Secondary vocational education, } \\
\text { professionally skilled worker, } \\
\text { white collar employee }\end{array}$ \\
\hline Entire staff & & $31,503.12$ & $31,735.92$ \\
\hline Secondary education & $50,727.41$ & $30,350.81$ \\
\hline Rate of return on investment in education & $30,350.81$ & $30,350.81$ & $5,198.23$ \\
\hline Net income & $7,222.2$ & $5,243.92$ & $-3,813.12$ \\
\hline
\end{tabular}

'Rate of return on investment in education is the required present value of additional income an individual derives, including the real interest rate, in line with the time and cost of education.

Source:Authoring 
Table 9

Benefits from investing in education by group, RUB

\begin{tabular}{lllll}
\hline Group & \multicolumn{2}{l}{ Education level } & & \\
\cline { 2 - 5 } & Higher & $\begin{array}{l}\text { Secondary vocational education, } \\
\text { mid-level specialist }\end{array}$ & $\begin{array}{l}\text { Secondary vocational education, } \\
\text { professionally skilled worker, white } \\
\text { collar employee }\end{array}$ & $\begin{array}{l}\text { Secondary } \\
\text { education }\end{array}$ \\
\hline Entire staff & $50,727.41$ & $31,503.12$ & $31,735.92$ & $30,350.81$ \\
\hline Leaders & $76,727.51$ & $49,159.8$ & $46,477.31$ & $44,734.22$ \\
\hline High qualification staff & 456,900 & $33,159.64$ & 339,061 & $38,721.15$ \\
\hline Mid-level qualification staff & $44,179.71$ & $31,976.91$ & $29,384.51$ & $30,481.83$ \\
\hline General workers (baseline level) & $20,381.28$ & $17,806.42$ & $18,167.9$ & $18,449.84$ \\
\hline Tuition fees & $7,222.2$ & $5,243.92$ & $5,198.23$ & - \\
\hline
\end{tabular}

Source:Authoring

\section{References}

1. Smith A. Issledovanie o prirode i prichinakh bogatstva narodov [An Inquiry into the Nature and Causes of the Wealth of Nations]. Moscow, Sotsekgiz Publ., 1935, pp. 234-235.

2. Maiburd E.M. Vvedenie v istoriyu ekonomicheskoi mysli. Ot prorokov do professorov [An Introduction to economic history. From prophets to professors]. Moscow, Delo Publ., 2000, 560 p.

3. Marshall A. Principles of Economics. New York, Macmillan Co, 1959.

4. Marshall A. Printsipy politicheskoi ekonomii. T1 [Principles of Political Economy. Vol. 1]. Moscow, Progress Publ., 1983.

5. Blaug M. [Economic Methodology in One Easy Lesson]. THESIS, 1994, no. 4. URL: https://igiti.hse.ru/data/018/314/1234/4_1_3Blaug.pdf

6. Blaug M. An Introduction to Economics of Education. London, Elsevier, 2014.

7. Marx K. Das Kapital. Writings, Vol. 1, 2nd ed. Vol. 23, 907 p. Moscow, Politizdat Publ., 1968.

8. Marx K. Das Kapital. Writings, Vol. 2, 2nd ed. Vol. 24, 648 p. Moscow, Politizdat Publ., 1968.

9. Schultz T.W. Investment in Human Capital. The American Economic Review, 1961, vol. 51, no. 1, pp. 1-17.

10. Schultz T. W. Human Capital: Policy Issues and Research Opportunities. In: Human Resources, Fiftieth Anniversary Colloquium VI. N. Y., 1975.

11. Walras L. Elements of Pure Economics. London, Allen and Unwin, 1954.

12. McCullox J.R. The Principles of Political Economy. Alex Murray \& Son, 1870.

13. Becker G.S. Chelovecheskoe povedenie: ekonomicheskii podkhod. Izbrannye trudy po ekonomicheskoi teorii [Human Behavior: Economical Approach. Selected works on economic theory]. Moscow, HSE Publ., 2003, 672 p.

14. Psacharopoulos G., Patrinos H.A. Returns to Investment in Education: A Further Update. Education Economics, 2004, vol. 12, no. 2, pp. 111-134. URL: https://doi.org/10.1080/0964529042000239140

15. Mincer J.B. Schooling, Experience and Earnings. New York, National Bureau of Economic Research, 1974. URL: http://www.nber.org/chapters/c1762.pdf

16. Becker G.S., Chiswick B.R. Education and the Distribution of Earnings. The American Economic Review, 1966, vol. 56, no. 1-2, pp. 358-369.

17. McConnell C.R., Brue S.L., Flynn S.M. Ekonomiks: printsipy, problemy i politika [Macroeconomics: Principles, Problems, and Policies]. Moscow, Respublika Publ., 1992, 400 p. 
18. Marx K. Kapital. Kritika politicheskoi ekonomii [Das Kapital. Kritik der politischen Ökonomie]. Moscow, Politizdat Publ., 2nd edition, 1974, vol. 49, 81 p.

19. Marx K. Kapital. Kritika politicheskoi ekonomii [Das Kapital. Kritik der politischen Ökonomie]. Moscow, Politizdat Publ., 2nd edition, 1974, vol. 23, 81 p.

20. Becker G.S. Human Capital and the Personal Distribution of Income: An Analytical Approach. Human Capital. 2nd ed. New York, Columbia University Press, 1975, pp. 94-144.

21. Becker G.S. Investment in Human Capital: A Theoretical Analysis. The Journal of Political Economy, 1962, vol. 70, no. 5, pp. 9-49. URL: https://doi.org/10.1086/258724

22. Jimenez E., Patrinos H.A. Can Cost-Benefit Analysis Guide Education Policy in Developing Countries? The World Bank Policy Research Working Paper, 2008, no. 4568, 42 p.

URL: https://openknowledge.worldbank.org/bitstream/handle/10986/6544/wps4568.pdf?sequence

23. Patrinos H.A., Psacharopoulos G. Returns to Education in Developing Countries. In: International Encyclopedia of Education, 2010, pp. 305-312. URL: https://doi.org/10.1016/B978-0-08-044894-7.01216-1

24. Bukreev I.A. [The problem of formation of future specialist with the requirements of the market]. Problemy sovremennogo pedagogicheskogo obrazovaniya = Problems of Modern Pedagogical Education, 2017, no. 56-2, pp. 39-51. URL: http://science.cfuv.ru/wp-content/uploads/2017/03/vyp-56-p-2-2017.pdf

\section{Conflict-of-interest notification}

We, the authors of this article, bindingly and explicitly declare of the partial and total lack of actual or potential conflict of interest with any other third party whatsoever, which may arise as a result of the publication of this article. This statement relates to the study, data collection and interpretation, writing and preparation of the article, and the decision to submit the manuscript for publication. 